\title{
Pengaturan Impor Pangan Negara Indonesia Berbasis pada Kedaulatan Pangan
}

\author{
Fauzin \\ Fakultas Hukum Universitas Trunojoyo Madura \\ Jl. Raya Telang No 02 Kamal Bangkalan Jawa Timur 69162 \\ *Email: fauzin@trunojoyo.ac.id \\ Naskah diterima 24 Januari 2021, Revisi 15 Maret 2021, Terbit 29 April 2021 \\ DOI: doi.org/10.21107/pamator.v14i1.10497
}

\begin{abstract}
The basic need that is needed by humans to fulfill their survival is food. Thus the basic needs in a country can be fulfilled by domestic products or foreign products which are commonly known as imports. Fulfilling this need for food is very important and strategic in order to maintain the sovereignty of the country, by not depending on food imports from developed countries. Law Number 18 of 2012 on Food, mandates the objectives of food administration, namely realizing food sovereignty, food self-sufficiency and food security. Therefore, it is necessary to increase the production and productivity of food commodities, especially strategic food in order to meet the needs of the community which are always increasing and directly proportional to the population. The method used is normative legal research.
\end{abstract}

Key words : food imports, food sovereignty, food security

\section{PENDAHULUAN}

Memasuki era globalisasi sekarang ini dan perdagangan bebas, serta persaingan hidup semakin tinggi, arus perdagangan barang dan/atau jasa semakin meluas bahkan melintasi batas-batas wilayah suatu negara dan kebutuhan masyarakat akan informasi juga semakin tinggi. Kebutuhan mendasar yang sangat dibutuhkan manusia untuk memenuhi keberlangsungan hidupnya adalah pangan. Pengertian tentang pangan sebagaimana diatur dalam Undang-Undang Nomor 18 Tahun 2012 tentang Pangan adalah segala sesuatu yang berasal dari produk pertanian, perkebunan, kehutanan, perikanan, peternakan, perairan baik yang diolah maupun tidak diolah yang diperuntukkan sebagai makanan atau minuman bagi konsumsi manusia, termasuk bahan tambahan pangan, bahan baku pangan dan bahan lainnya yang digunakan dalam proses penyiapan, pengolahan, dan/atau pembuatan makanan atau minuman.

Kebutuhan pokok di suatu negara dapat dipenuhi oleh produk negeri ataupun produk luar negeri yang biasa dikenal dengan impor. Perdagangan internasional berupa ekspor dan impor barang dan jasa antar Negara sudah tidak dapat dipungkiri lagi. Sejak diberlakukannya pasar bebas, barang dan jasa dari luar negeri beredar secara bebas di pasar Indonesia dan sebagai konsekuensinya produk-produk dari luar negeri banyak dijumpai di Indonesia sendiri.

Indonesia adalah salah satu negara agraris, berdasarkan data Badan Pusat Statistik (BPS) pertanian merupakan sektor lapangan pekerjaan masih mendominasi sebesar 27,33\%, dibandingkan sektor perdagangan $(18,81 \%)$ dan industri pengolahan $(14,96 \%)$. Pangan merupakan kebutuhan dasar utama manusia yang harus dipenuhi setiap saat sehingga ketersediaannya harus terjamin dan terpenuhi. Hak untuk memperoleh pangan merupakan salah satu hak asasi manusia, sebagaimana tersebut dalam pasal 27 UUD 1945 maupun dalam Deklarasi Roma (1996). Pertimbangan tersebut mendasari terbitnya UU No. 7 Tahun 1996 tentang Pangan. Sebagai kebutuhan dasar dan salah satu hak asasi manusia, pangan mempunyai arti dan peran yang sangat penting bagi kehidupan suatu bangsa.

Ketersediaan pangan yang lebih kecil dibandingkan kebutuhannya dapat menciptakan ketidak-stabilan ekonomi. Berbagai gejolak sosial dan politik dapat juga terjadi jika ketahanan pangan terganggu. 
Kondisi pangan yang kritis ini bahkan dapat membahayakan stabilitas ekonomi dan stabilitas nasional. Dengan demikian pemenuhan kebutuhan pangan ini menjadi sangat penting dan strategis dalam rangka mempertahankan kedaulatan negara, melalui tidak tergantung pada impor pangan dari negara maju. Ketergantungan suatu negara akan impor pangan (apalagi dari negara maju), akan mengakibatkan pengambilan keputusan atas segala aspek kehidupan menjadi tidak bebas atau tidak merdeka, dan karenanya negara menjadi tidak berdaulat secara penuh. Tren negatif laju pertumbuhan ekonomi dunia diprediksi terus berlanjut di tahun 2020 dan akan semakin parah dengan ancaman resesi global di depan mata akibat merebaknya pandemi Covid-19.

Negara maju memberikan pemahaman yang positif tentang perdagangan bebas walaupun sesungguhnya sangat merugikan negara berkembang. Perubahan pada tatanan perekonomian dan perdagangan dunia akan menyebabkan banyak negara yang dirugikan adalah negara yang belum siap, terutama negara berkembang dalam teknologi, sumber daya alam, dan juga sosial masyarakatnya yang belum mampu menerima perubahan-perubahan dalam kehidupan sehari-hari. Berkembangnya perdagangan internasional membuat beberapa negara melakukan kerjasama Internasional.

Ketahanan pangan tidak lepas dari sifat produksi komoditi pangan itu sendiri yang musiman dan berfluktuasi karena sangat mudah dipengaruhi oleh iklim/cuaca. Perilaku produksi yang sangat dipengaruhi iklim tersebut yang sangat mempengaruhi ketersediaan pangan nasional. Kalau perilaku produksi yang rentan terhadap perubahan iklim tersebut tidak dilengkapi dengan kebijakan pangan yang tangguh maka akan sangat merugikan, baik untuk produsen maupun konsumen, khususnya produsen berskala produksi kecil dan konsumen berpendapatan rendah. Karakteristik komoditi pangan yang mudah rusak, lahan produksi petani yang terbatas; sarana dan prasarana pendukung pertanian yang kurang memadai dan lemahnya penanganan panen dan pasca panen mendorong Pemerintah untuk melakukan intervensi dengan mewujudkan kebijakan ketahanan pangan. Kedaulatan pangan merupakan suatu strategi dasar untuk melengkapi ketahanan pangan sebagai tujuan akhir pembangunan pangan, karena kedua konsep ini sesungguhnya sejalan dan saling melengkapi.

\section{METODOLOGI}

Metode penulisan ini menggunakan tipe penelitian hukum normatif, penelitian yang dilakukan dengan berlandaskan pada peraturan perundang-undangan yang berlaku terkait dengan pembahasan penulisan ini yaitu mengatur tentang Pangan dan bahan-bahan hukum lainnya baik yang bersifat sekunder yang ada di perpustakaan maupun jurnal hukum lainnya. Sedangkan pendekatan masalah dalam penulisan ini menggunakan pendekatan masalah dengan melalui Pendekatan Perundang-undangan (statute approach) dan Pendekatan Konseptual (conceptual approach). Pendekatan perundang-undang atau statute approach dilakukan dengan menelaah semua Undang-undang dan regulasi untuk keperluan praktik hukum yang tidak dapat melepaskan diri dari pendekatan perundangundangan dengan isu hukum yang dikaji. Pendekatan konseptual atau conceptual approach dilakukan dengan ditemukan dalam dari pandangan-pandangan sarjana ataupun doktrin-doktrin yang berkembang di dalam ilmu hukum (Peter, 2008).

\section{HASIL PEMBAHASAN}

Pangan sebagai salah satu jenis yang mempengaruhi hajat hidup orang banyak, temyata diperlakukan sebagai komoditi ekonomi semata. Makanan merupakan kebutuhan manusia yang paling mendasar. Tanpa makanan, manusia tidak dapat bertahan hidup karena pasokan energi bagi manusia bersumber dari makanan tersebut. Ketersediaan pangan yang lebih kecil dibandingkan kebutuhannya dapat menciptakan ketidak-stabilan ekonomi. Berbagai gejolak sosial dan politik dapat juga terjadi jika ketahanan pangan terganggu. Kondisi pangan yang kritis ini bahkan dapat membahayakan stabilitas ekonomi dan stabilitas nasional.

\section{Pangan Impor}

Pengertian pangan impor dapat dilihat dalam pasal 1 angka (25) Undang-Undang Nomor 18 tahun 2012 tentang Pangan yang 
menyebutkan bahwa impor pangan adalah kegiatan memasukkan pangan ke dalam daerah pabean negara Republik Indonesia yang meliputi wilayah darat, perairan, dan ruang udara di atasnya, tempat-tempat tertentu di Zona Ekonomi Eksklusif, dan landas kontinen.

Kegiatan impor pangan hanya dapat dilakukan apabila produksi pangan dalam negeri tidak mencukupi dan/atau tidak dapat diproduksi didalam negeri. Impor pangan pokok juga dapat dilakukan apabila produksi pangan dalam negeri dan cadangan pangan nasional tidak mencukupi. Impor Pangan yang dilakukan untuk memenuhi kebutuhan konsumsi dalam negeri wajib memenuhi persyaratan keamanan, mutu, gizi, dan tidak bertentangan dengan agama, keyakinan, dan budaya masyarakat.

Pangan yang diimpor harus benar-benar memenuhi kandungan gizi dan standar keamanan bagi kesehatan karena kesehatan merupakan hak asasi setiap orang. Berdasarkan pasal 48 Undang-Undang Nomor 36 Tahun 2009 tentang Kesehatan menyatakan bahwa melalui kegiatan pengamanan makanan dan minuman merupakan salah satu cara untuk mewujudkan derajat kesehatan yang setinggi-tingginya.

\section{Kedaulatan Pangan}

Berdasarkan Pasal 1 angka 2 UndangUndang Nomor 18 tentang Pangan, Kedaulatan Pangan adalah hak negara dan bangsa yang secara mandiri menentukan kebijakan pangan yang menjamin hak atas pangan bagi rakyat dan yang memberikan hak bagi masyarakat untuk menentukan sistem pangan yang sesuai dengan potensi sumber daya lokal.

Kedaulatan pangan dapat diposisikan sebagai strategi pokok untuk mencapai tujuan pembangunan pangan nasional, yakni ketahanan pangan. Kedaulatan pangan tidak menggantikan, namun menjadi pelengkap atau pendukung bahkan menjadi basis untuk tercapainya ketahanan pangan yang sejati. Dengan mengimplementasikan spirit kedaulatan pangan, maka ketahanan pangan di Indonesia akan lebih mampu dicapai secara kokoh dan berkeadilan. Konsep kedaulatan pangan dilahirkan pertama kali saat pertemuan petani yang dibentuk tahun 1992 pada Kongres The National Union of
Farmers and Livestock Owners (UNAG). Kegiatan ini dikoordinasikan oleh petani yang tersebar mulai dari Afrika, Amerika Utara, Tengah, dan Selatan, Asia, Karibia, dan Eropa. Para pencetus dan penggerak ini berada dalam organisasi Via Campesina yang mencakup Family Farmers' Association (UK), Confederation Paysanne (France), Bharatiya Kisan Union (India), Landless Workers' Movement (Brazil), National Family Farm Coalition (USA) dan para petani tak bertanah Landles Peoples' Movement (South Africa). (Syahyuti, Sunarsih, Sri , Wahyuning, \& Miftahul, 2015)

\section{Ketahanan Pangan}

Pengertian ketahanan pangan, tidak lepas dari Undang-Undang 2012 tentang Pangan. Disebutkan dalam UU tersebut bahwa ketahanan pangan adalah kondisi terpenuhinya pangan bagi negara sampai dengan perseorangan, yang tercermin dari tersedianya pangan yang cukup, baik jumlah maupun mutunya, aman, beragam, bergizi, merata, dan terjangkau serta tidak bertentangan dengan agama, keyakinan, dan budaya masyarakat untuk dapat hidup sehat, aktif, dan produktif secara berkelanjutan.

Definisi ketahanan pangan dalam UU No 18 tahun 2012 diatas merupakan penyempurnaan dan "pengkayaan cakupan" dari definisi dalam UU No 7 tahun 1996 yang memasukkan "perorangan" dan "sesuai keyakinan agama" serta "budaya" bangsa. Definisi UU No 18 tahun 2012 secara substantif sejalan dengan definisi ketahanan pangan dari FAO yang menyatakan bahwa ketahanan pangan sebagai suatu kondisi dimana setiap orang sepanjang waktu, baik fisik maupun ekonomi, memiliki akses terhadap pangan yang cukup, aman, dan bergizi untuk memenuhi kebutuhan gizi sehari-hari sesuai preferensinya.

\section{Pengaturan Impor Pangan Indonesia}

Berdasarkan Lampiran Peraturan Menteri Perdagangan Republik Indonesia Nomor 46 Tahun 2020 Tentang Rencana Strategis Kementerian Perdagangan Tahun 20202024, pengendalian impor dilakukan terhadap barang konsumsi dan barang untuk kebutuhan industri. Terhadap barang konsumsi, pengelolaan impor dilakukan dalam rangka meningkatkan ketahanan pangan. Ketahanan pangan nasional masih 
merupakan isu yang strategis bagi Indonesia mengingat masih belum terpenuhinya kecukupan produksi, yang disertai dengan belum optimalnya sistem distribusi dan tingginya tingkat konsumsi menciptakan keterkaitan yang tinggi dengan masalah sosial, ekonomi dan politik.

Pada saat yang sama terdapat upaya dalam rangka memperbaiki peringkat kemudahan berusaha (Ease of Doing Business/ EODB) yang salah satunya dengan melakukan penggeseran pengawasan larangan dan pembatasan (lartas) impor dari border ke post border. Artinya, pemeriksaan atas pemenuhan persyaratan impor dilakukan setelah melalui kawasan pabean. Perubahan ini diharapkan dapat memperlancar proses masuk barang. Selain itu, transaksi importir diharapkan menjadi lebih mudah karena dapat mencegah biaya kelebihan waktu pemakaian peti kemas. Komoditas yang masuk kategori di post border didominasi dari golongan bahan baku, sedangkan bahan pangan atau barang lainnya yang memiliki risiko tinggi dan menyangkut keamanan, kesehatan, keselamatan dan lingkungan hidup, akan tetap diperiksa melalui border.

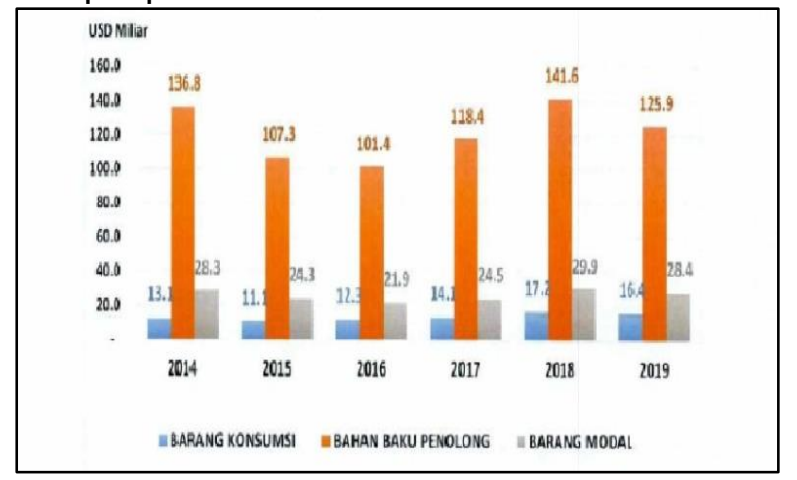

Gambar 1. Pertumbuhan Impor Indonesia (Sumber : BPS, 2020)

Namun, kebijakan post border untuk menurunkan biaya logistik dan dwelling time, dinilai belum efektif mendorong pertumbuhan ekonomi dalam negeri. Kebijakan ini berpotensi dimanfaatkan importir dengan memasukkan produk tanpa pengawasan yang ketat. Pengawasan di bawah Kementerian Perdagangan dinilai belum cukup mumpuni untuk menutup celah kecurangan impor barang. Salah satu bentuk kecurangannya adalah mengubah harmonized system (HS), sehingga yang awalnya dikenakan larangan atau dibatasi menjadi tidak terdeteksi. Disamping itu, kebijakan post border juga dirasa menunjukkan lemahnya pengawasan sebab barang bisa melewati wilayah pabean. Artinya barang sudah benar-benar masuk, baru terjadi pemeriksaan dan pemenuhan syarat.

Hal ini hanya dapat menguntungkkan beberapa pihak seperti investor dan importir yang mudah memasukkan barang impor tanpa kendali yang ketat. Pada sisi lain, ada keinginan kuat untuk melakukan pengetatan impor namun juga pelaksanaan post border yang malah melonggarkan barang impor masuk tanpa pengecakan dan verifikasi di daerah pabean. Perlu penelaahan lanjutan terkait kebijakan ini, karena terkait dengan persoalan pengamanan perdagangan nasional.

Ketergantungan Impor pangan juga termasuk pengaruh globalisasi dengan ideologi neoliberalisme telah memaksakan petani dan Negara membuat pilihan yang tidak nyaman dan saling bertentangan. Pakar ekonomi pertanian, Francis Wahono, menilai bahwa pilihan kebijakan dan praktik pemerintah banyak yang melantarkan rakyat, termasuk petani (Wahono, 2011). Praktik impor beras misalnya, terkadang zero tariff.

Pada tahun 2020, dinamika perekonomian global yang terjadi seperti, perlambatan laju pertumbuhan ekonomi dunia, penurunan harga komoditas dunia, meningkatnya tensi geopolitik di sejumlah Kawasan dan ancaman perang dagang antara Amerika Serikat dan Republik Rakyat Tiongkok (RRT) dan pandemi Covid-19, menjadi peluang dan tantangan tersendiri dalam membangun perekonomian nasional kedepan. Bank Dunia memperkirakan perekonomian Indonesia tahun 2020 akan tetap stabil dan berdaya tahan. Isu perekonomian dunia seperti melemahnya volume perdagangan dunia, terutama yang terjadi pada tahun 2020 karena pandemi Covid-19 diprediksi tidak banyak mempengaruhi perekonomian nasional karena roda penggerak perekonomian nasional masih didominasi oleh konsumsi domestik. Tingginya proporsi konsumsi domestik terhadap PDB, bahkan mampu menutupi dampak negatif dari defisit neraca perdagangan yang telah terjadi tahun 2018 dan 2019 (Rencana Strategis Kementerian Perdagangan 2020-2024, 2020). 
Indonesia memberlakukan baik hambatan tarif maupun non-tarif untuk impor pangan. Hambatan tarif menambahkan tarif impor rata-rata untuk produk pangan sebesar $6,39 \%$ pada tahun 2018. Sementara untuk hambatan non-tarif, termasuk di dalamnya pembatasan kuota, penetapan sanitarifitosanitari (misalnya karantina, inspeksi kualitas), dan hambatan teknis perdagangan lainnya (misalnya pengemasan, pelabelan). Hambatan-hambatan perdagangan ini menambahkan ekstra $41 \%$ di atas kegiatankegiatan penambah nilai di seluruh rangkaian rantai pasokan (Marks, 2017).

Sektor swasta harus mendapatkan kuota dan izin dalam bentuk Surat Persetujuan Impor (SPI) melalui sistem perizinan impor non-otomatis yang dikeluarkan oleh Kementerian Perdagangan setelah mendapatkan surat rekomendasi dari Kementerian Pertanian. Jumlah kuota diatur melalui rapat koordinasi antara lima kementerian dan badan pemerintah yang berbeda dan juga berdasarkan data dan stok produksi yang sering dianggap tidak akurat (Ruslan, 2019). Proses ini juga memakan waktu dan berakibat kelangkaan serta kenaikan harga seperti yang dilaporkan oleh berbagai media (Rosana, 2020).

Penyebaran wabah Covid-19 telah menimbulkan kekhawatiran akan ketahanan pangan di seluruh dunia, termasuk di Indonesia, karena adanya gangguan produksi dan rantai pasokan. Pasar serealia global tahun 2019/2020 diprediksi akan tetap memiliki pasokan yang cukup (FAO, 2020). Selaras dengan hal itu, Kementerian Pertanian Indonesia (2020) mengklaim bahwa pasokan beras akan cukup hingga Agustus, dengan prediksi panen sebesar 12,4 juta ton sepanjang Maret hingga Mei. Akan tetapi, Indonesia mengalami kelangkaan komoditas pangan lainnya seperti bawang putih, daging sapi, dan gula, yang merupakan komoditas penting selama bulan Ramadhan (Felippa \& Ira, 2020).

Indonesia tetap bergantung pada impor pangan. Pada 2018, 95\% pasokan bawang putih Indonesia, 24\% pasokan daging sapi, dan $55 \%$ pasokan gula datang dari luar negeri, dan Kementerian Perdagangan telah memulai impor di tahun 2020 (Asogiyan, 2018; Respatiadi \& Nabila, 2017; McDonald \& Meylinah, 2019; Kementerian Pertanian, 2020). Pada tahun 2018, Indonesia merupakan net importir terhadap produk pangan senilai USD 576,18 juta. Ketahanan pangan sangat erat kaitannya dengan tingkat inflasi yang dapat mengganggu pertumbuhan ekonomi. Terhadap barang untuk kebutuhan industri, pengelolaan barang impor berperan penting dalam meningkatkan daya saing produk ekspor Indonesia melalui pengelolaan impor barang modal dan bahan baku/ penolong yang digunakan di dalam proses produksi untuk tujuan ekspor. Dalam rangka menjaga ketersediaan pasokan pangan dan kebutuhan industri di dalam negeri diperlukan suatu kebijakan impor yang dinamis dan komprehensif. Pemerintah telah mengeluarkan kebijakan-kebijakan terkait impor, dimana kebijakan tata niaga impor tersebut belum optimal pelaksanaannya.

Pemenuhan konsumsi pangan tersebut harus mengutamakan produksi dalam negeri dengan memanfaatkan sumber daya dan kearifan lokal secara optimal. Untuk mewujudkan hal tersebut, tiga hal pokok yang harus diperhatikan adalah

(i) Ketersediaan pangan yang berbasis pada pemanfaatan sumber daya lokal secara optimal,

(ii) Keterjangkauan pangan dari aspek fisik dan ekonomi oleh seluruh masyarakat, serta

(iii) Pemanfaatan pangan atau konsumsi pangan dan gizi untuk hidup sehat, aktif, dan produktif.

Perwujudan ketersediaan pangan yang berbasis pada pemanfaatan sumber daya lokal secara optimal dilakukan dengan penganekaragaman pangan dan pengutamaan produksi pangan dalam negeri. Pewujudan keterjangkauan pangan dari aspek fisik dan ekonomi dilakukan melalui pengelolaan stabilisasi pasokan dan harga pangan pokok, pengelolaan cadangan pangan pokok, dan pendistribusian pangan pokok. Pemanfaatan pangan atau konsumsi pangan dan gizi akan menghasilkan sumber daya manusia yang berkualitas sebagai salah satu faktor penentu keberhasilan pembangunan.

Indonesia dapat mempertimbangkan untuk menghapus sebagian dari hambatan perdagangannya di sektor pangan dan pertanian, seperti tarif, larangan kuantitatif, dan sistem perizinan impor non-otomatis untuk komoditas-komoditas pangan utama. Jika tarif dihapus, harga impor komoditas 
pertanian tetap akan meningkat, tetapi hanya sebesar $0,65 \%$ jika dibandingkan dengan $1,20 \%$ di bawah skenario BAU (Mckibbin \& Fernando, 2020).

Green et al. memperkirakan bahwa kenaikan harga pangan sebesar $1 \%$ mengurangi konsumsi sebesar 0,68\% di negara dengan pendapatan menengah seperti Indonesia (Green, et al., 2013). Dengan demikian, eliminasi tarif bisa meningkatkan konsumsi rumah tangga sebesar $0,38 \%$ lebih tinggi dibandingkan konsumsi dalam skenario BAU (Felippa \& Ira, 2020).

Peraturan Kementerian Perdagangan Nomor 27 Tahun 2020 telah menghapus persyaratan SPI untuk bawang putih dan bawang bombay pada Maret 2020 untuk mengurangi kelangkaan. Harga bawang putih turun signifikan dari Rp55.200,- per kilogram di bulan Februari menjadi Rp40.650,- per kilogram pada 23 April 2020, berkurang sebesar $26,36 \%$ dalam 10 minggu. Kondisi tersebut menyiratkan bahwa penghapusan SPI dan kuota dapat membantu Indonesia mempercepat proses impornya juga untuk komoditas lainnya, seperti daging sapi dan gula.

\section{Konsep Kedaulatan Pangan Dan Tantangan Mewujudkan Ketahanan Pangan Berkelanjutan}

Indonesia sebagai negara yang memiliki sumber daya alam melimpah dan budaya agraris mutlak harus dapat memenuhi kebutuhan bahan pangan dari pertaniannya sendiri. Ketergantungan bahan pangan dari negara lain merupakan kelemahan yang harus dapat diatasi. Selama ini, kebijakan pangan nasional terkait dengan lima aspek utama, meliputi: hulu (kapasitas produksi pangan), hilir (panen dan pascapanen), infrastruktur pertanian, alokasi anggaran, serta kelembagaan. Kelima aspek tersebut harus dilakukan secara komprehensif karena saling terkait, melibatkan seluruh pemangku kepentingan, dan bersifat lintas sektor (Lukman, 2014).

Kedaulatan pangan adalah konsep yang lahir sebagai respon dari kekecewaan pembangunan pangan yang terjadi di banyak belahan dunia. Meskipun pembangunan pertanian dan pangan telah mampu mencapai produksi dan produktivitas yang tinggi, namun sebagian petani terutama di negara berkembang hidup dalam kondisi yang jauh dari sejahtera, berlangsungnya kerusakan sumber daya pertanian, dan juga perdagangan yang tidak adil. Banyak pihak tidak puas terhadap kondisi pangan lokal dan perdagangan pangan dunia. Bukti menunjukkan bahwa meskipun ketahanan pangan tercapai, namun belum mampu menjamin kondisi pangan lokal dan juga tidak mampu mengangkat martabat petani (Lukman, 2014).

Tabel 1. Deskripsi Konsep dan Pendekatan Kedaulatan Pangan Serta Sumber Hukumnya

\begin{tabular}{|c|c|c|}
\hline $\begin{array}{c}\text { Kedaulatan } \\
\text { terhadap }\end{array}$ & Deskripsinya & Sumber \\
\hline 1. Lahan Usaha & $\begin{array}{l}\text { Petani } \\
\text { berusaha di } \\
\text { atas lahan } \\
\text { miliknya } \\
\text { sendiri, } \\
\text { sehingga hasil } \\
\text { produksi } \\
\text { mencukupi } \\
\text { untuk } \\
\text { kesejahteraan } \\
\text { keluarganya. }\end{array}$ & $\begin{array}{l}\text { Nawacita, } \\
\text { definisi } \\
\text { internasional }\end{array}$ \\
\hline $\begin{array}{l}\text { 2. Sumber daya } \\
\text { air untuk } \\
\text { pertanian }\end{array}$ & $\begin{array}{l}\text { Petani dan } \\
\text { komunitas } \\
\text { petani } \\
\text { diberikan } \\
\text { alokasi air } \\
\text { irigasi yang } \\
\text { cukup untuk } \\
\text { kebutuhan } \\
\text { usaha taninya } \\
\text { secara teknis. }\end{array}$ & Nawacita \\
\hline $\begin{array}{l}\text { 3. Benih dan } \\
\text { bibit }\end{array}$ & $\begin{array}{l}\text { Petani dan } \\
\text { komunitas } \\
\text { petani } \\
\text { menanam } \\
\text { benih/bibit } \\
\text { yang mereka } \\
\text { inginkan dan } \\
\text { merupakan } \\
\text { produksi } \\
\text { mereka } \\
\text { sendiri dan } \\
\text { tidak } \\
\text { bergantung } \\
\text { kepada pasar. }\end{array}$ & $\begin{array}{l}\text { Nawacita, } \\
\text { definisi } \\
\text { internasional }\end{array}$ \\
\hline $\begin{array}{l}\text { 4. Pupuk dan } \\
\text { obat-obatan }\end{array}$ & $\begin{array}{l}\text { Petani } \\
\text { terjamin } \\
\text { kebutuhan } \\
\text { pupuk dan } \\
\text { obat-obatan } \\
\text { sesuai } \\
\text { dengan siklus } \\
\text { usahanya. }\end{array}$ & $\begin{array}{l}\text { Nawacita, } \\
\text { SIPP }\end{array}$ \\
\hline $\begin{array}{l}\text { 5. System } \\
\text { pertanian }\end{array}$ & $\begin{array}{l}\text { Petani } \\
\text { diberikan } \\
\text { keleluasaan } \\
\text { untuk }\end{array}$ & $\begin{array}{l}\text { UU Pangan } \\
\text { pasal } 1 \text { dan } \\
130, \\
\text { Peasant }\end{array}$ \\
\hline
\end{tabular}




\begin{tabular}{|c|c|c|}
\hline \multirow{2}{*}{$\begin{array}{c}\text { Kedaulatan } \\
\text { terhadap }\end{array}$} & Deskripsinya & Sumber \\
\hline & $\begin{array}{l}\text { menentukan } \\
\text { cara Bertani } \\
\text { yang sesuai } \\
\text { dengan teknis } \\
\text { dan } \\
\text { sosiokulturnya }\end{array}$ & $\begin{array}{l}\text { Charter, } \\
\text { definisi } \\
\text { internasional }\end{array}$ \\
\hline $\begin{array}{l}\text { 6. Hasil } \\
\text { produksi }\end{array}$ & $\begin{array}{l}\text { Petani } \\
\text { memiliki } \\
\text { kuasa atas } \\
\text { hasil } \\
\text { produksinya } \\
\text { sendiri, dan } \\
\text { baru akan } \\
\text { tercapai } \\
\text { optimal bila } \\
\text { mereka bukan } \\
\text { petani } \\
\text { penggarap } \\
\text { dan juga tidak } \\
\text { terikat hutang } \\
\text { dengan } \\
\text { pedagang. }\end{array}$ & $\begin{array}{l}\text { Nawacita, } \\
\text { definisi } \\
\text { internasional }\end{array}$ \\
\hline $\begin{array}{l}\text { 7. Pangan } \\
\text { konsumsi dan } \\
\text { pilihan } \\
\text { mengonsumsi }\end{array}$ & $\begin{array}{l}\text { Petani dapat } \\
\text { mengonsumsi } \\
\text { pangan } \\
\text { sesuai } \\
\text { dengan } \\
\text { preferensi dan } \\
\text { kebiasaan } \\
\text { sosiokultur } \\
\text { mereka } \\
\text { sendiri. }\end{array}$ & $\begin{array}{l}\text { UU Pangan } \\
\text { pasal } 3, \\
\text { Nawacita, } \\
\text { definisi } \\
\text { internasional }\end{array}$ \\
\hline
\end{tabular}

Sumber : (Syahyuti, Sunarsih, Sri , Wahyuning, \& Miftahul, 2015)

Berdasarkan Undang-Undang Nomor 18 Tahun 2012 tentang Pangan memberikan batasan terhadap kedaulatan pangan sebagai hak negara dan bangsa yang secara mandiri menentukan kebijakan pangan yang menjamin hak atas pangan bagi rakyat dan yang memberikan hak bagi masyarakat untuk menentukan sistem pangan yang sesuai dengan potensi sumber daya lokal. Sedangkan kemandirian pangan didefinisikan sebagai kemampuan negara dan bangsa dalam memproduksi pangan yang beraneka ragam dari dalam negeri yang dapat menjamin pemenuhan kebutuhan pangan yang cukup sampai di tingkat perseorangan memanfaatkan potensi sumber daya alam, manusia, sosial, ekonomi dan kearifan lokal secara bermartabat.

Kedaulatan pangan yang dimaksud Undang-Undang ini adalah sebagaimana yang disebutkan dalam Pasal 1 angka 2, yaitu: hak negara dan bangsa yang secara mandiri menentukan kebijakan pangan yang menjamin hak atas pangan bagi rakyat dan yang memberikan hak bagi masyarakat untuk menentukan sistem pangan yang sesuai dengan potensi sumber daya lokal.

Undang-Undang Pangan bukan hanya berbicara tentang ketahanan pangan, namun juga memperjelas dan memperkuat pencapaian ketahanan pangan dengan mewujudkan kedaulatan pangan (food soveregnity) dengan kemandirian pangan (food resilience) serta keamanan pangan (food safety). Kedaulatan pangan adalah hak negara dan bangsa yang secara mandiri menentukan kebijakan pangan yang menjamin hak atas pangan bagi rakyat dan yang memberikan hak bagi masyarakat untuk menentukan sistem pangan yang sesuai dengan potensi sumber daya lokal.

Kedaulatan pangan lebih menitikberatkan pada kemandirian pangan, perlindungan kepada petani dan ekosistem lokal, dengan memerhatikan aspek pangan maupun manusianya. Pangan seharusnya tidak ditumpukan pada pasar yang rentan, tetapi pada kemandirian dalam mencukupinya. Dalam konteks negara besar, seperti Indonesia, ketergantungan terhadap pangan impor adalah ironi, karena selain mengabaikan potensi dan kekayaan sumber daya lokal juga bisa membawa ancaman bagi stabilitas nasional (Syahyuti, 2011). Ketahanan pangan merupakan konsep yang diterima luas di berbagai negara dan telah berjalan cukup lama. Konsep "ketahanan pangan" (food security) sejak akhir tahun 1970-an, sedangkan "kedaulatan pangan" mulai diwacanakan semenjak tahun 1992 atau lebih dari 30 tahun setelahnya.

Adapun ketahanan pangan didefinisikan sebagai kondisi terpenuhinya pangan bagi negara sampai dengan perseorangan, yang tercermin dari tersedianya pangan yang cukup, baik jumlah maupun mutunya, aman, beragam, bergizi, merata, dan terjangkau serta tidak bertentangan dengan agama, keyakinan, dan budaya masyarakat, untuk dapat hidup sehat, aktif, dan produktif secara berkelanjutan.

Faktor-faktor yang berpengaruh terhadap ketahanan pangan keluarga yang meliputi: sistem informasi, produksi pangan, cadangan pangan, daya beli, kesempatan kerja, pendidikan, infrastruktur perdesaan, beban keluarga, pengeluaran nonpangan, akses terhadap permodalan, dan organisasi sosial. Terhadap faktorfaktor tersebut diperlukan 
strategi penguatan kondisi sosial ekonomi masyarakat menuju ketahanan pangan keluarga yang dilakukan antara lain melalui: peningkatan akses petani terhadap teknologi, kredit, sarana produksi, dan pasar; pembangunan infrastruktur pertanian; stabilisasi dan informasi harga pangan; serta ketersediaan pasar secara lokal (Hanani, 2012).

Untuk mencapai ketahanan pangan dapat dilakukan dengan cara melakukan peningkatan produktivitas hasil pertanian, yakni dengan cara memperkenalkan jenis varietas unggul sehingga nantinya petani memperoleh peningkatan pendapatan. Melalui peningkatan pendapatan tersebut, petani diharapkan dapat membeli kebutuhan pangan mereka, selain itu upaya lain yang dilakukan pemerintah adalah dengan cara melakukan impor beras untuk mencukupi stock pangan nasional. Pandangan seperti ini tidak salah, tetapi upaya membangun ketahanan pangan yang berdampak terhadap menghilangkan sistem pangan lokal dan ketergantungan terhadap beras impor dalam jangka panjang dapat mengakibatkan terjadinya rawan pangan.

Permasalahan sehubungan dengan ketahanan pangan adalah penyediaan, distribusi dan konsumsi pangan. Penyediaan dihadapkan pada semakin terbatas dan menurunnya kapasitas produksi. Distribusi dihadapkan pada permasalahan prasarana dsitribusi darat dan antar pulau, kelembagaan dan keamanan jalur distribusi, serta bervariasinya kapasitas produksi antar wilayah dan antar musim. Permasalahan konsumsi adalah belum terpenuhinya kebutuhan pangan, karena belum tercukupinya konsumsi energi (meskipun konsumsi protein sudah mencukupi), serta konsumsi energi yang sebagian besar dari padi-padian, dan bias ke beras.

Prinsip kedaulatan pangan berbeda dengan ketahanan pangan yang tidak mempedulikan asal produksi pangan. Kedaulatan pangan cenderung menjunjung tinggi hak setiap warga dan masyarakat lokal sebagai satu kesatuan produksi, distribusi, dan pemenuhan kebutuhan pangan di atas semua kepentingan lain. Namun, konsep kedaulatan pangan tidak bertentangan dengan prinsip ketahanan pangan. Upaya membangun ketahanan pangan tanpa diikuti dengan upaya menegakkan kedaulatan pangan akan melahirkan persoalan sosial baru, seperti ketergantungan terhadap beras impor dan rendahnya produktivitas petani. Beberapa prinsip kedaulatan pangan adalah: (Lukman, 2014).

a. menghormati dan memperkuat kearifan tradisional serta pengetahuan lokal dalam memproduksi pertanian pangan lokal sebagai landasan sistem produksi pangan berkelanjutan;

b. pengakuan dan penghormatan terhadap budaya yang khas dalam memilih dan mengonsumsi pangan serta hak untuk menentukan sendiri dalam jumlah cukup, bergizi, dan aman;

c. rakyat desa berdaulat dalam menentukan kebijakan dan strategi produksi, distribusi, dan konsumsi pangannya sendiri, terutama untuk memprioritaskan peningkatan produksi pangan dalam rangka pemenuhan pangan seluruh warga desa; dan

d. keluarga miskin dan kurang pangan yang ada di desa mendapat prioritas untuk mengakses berbagai sumber produktif.

Pangan yang diatur dalam Undangundang, komoditas pangan berasal dari produk pertanian, perkebunan, kehutanan, dan perikanan, baik yang diolah maupun tidak diolah, yang diperuntukkan sebagai makanan atau minuman bagi manusia. Pengembangan komoditas pangan dipengaruhi oleh faktor lahan dan input produksi, seperti jumlah ternak, pupuk, bibit/benih, dan faktor pembiayaan. Kajian ini dibatasi pada komoditas pangan yang berasal dari produk pertanian, termasuk di dalamnya peternakan dan perkebunan (Lukman, 2014). Strategi menuju ketahanan pangan Indonesia berkelanjutan 2025 dikelompokkan menurut subsistem dalam sistem ketahanan pangan seperti diatur dalam UU Pangan, yaitu ketersediaan pangan, keterjangkauan pangan, dan pemanfaatan pangan (Suryana A. , 2014). Saat ini, ketahanan, kemandirian, dan kedaulatan pangan mengalami kerentanan karena mudah terimbas pengaruh gejolak fluktuasi harga di pasar internasional dan perubahan iklim.

\section{KESIMPULAN}

Peraturan-peraturan yang mendukung kebijakan pemerintah untuk melakukan impor 
pangan di Indonesia, selalu dikaitkan dengan persoalan ketersediaan dan ketahanan pangan. Kenyataan tentang semakin menurunnya angka ketahanan pangan dan kemiskinan yang diderita mayoritas petani di Indonesia, menjadi realitas paradoks dengan semua tujuan yang menjadi retorika dari keluamya peraturan tersebut. Berdasarkan realitas ketidaksejahteraan yang semakin meningkat, maka semua peraturan tentang impor beras harus direvisi, karena tidak mendukung tujuan negara kesejahteraan Indonesia, sebagaimana yang diamanatkan UUD 1945 dan Pancasila. Undang-Undang Nomor 18 Tahun 2012 tentang Pangan telah mengamanatkan tujuan penyelenggaraan pangan, yaitu mewujudkan kedaulatan pangan, kemandirian pangan, dan ketahanan pangan. Oleh karena itu, diperlukan peningkatan produksi dan produktivitas komoditas pangan, terutama pangan strategis, agar dapat memenuhi kebutuhan masyarakat yang selalu meningkat dan berbanding lurus dengan jumlah penduduk.

Kedaulatan pangan dapat diposisikan sebagai strategi pokok untuk mencapai tujuan pembangunan pangan nasional, yakni ketahanan pangan. Kedaulatan pangan tidak menggantikan, namun menjadi pelengkap atau pendukung bahkan menjadi basis untuk tercapainya ketahanan pangan yang sejati. Dengan mengimplementasikan spirit kedaulatan pangan, maka ketahanan pangan di Indonesia akan lebih mampu dicapai secara kokoh dan berkeadilan. Perwujudan ketahanan pangan pada tingkat makro (nasional dan global) ke depan akan semakin sulit karena kecenderungan pergerakan penawaran dan permintaan pangan menuju ke arah yang berlawanan.

\section{DAFTAR PUSTAKA}

Achmad Suryana, Menuju ketahanan pangan indonesia berkelanjutan 2025: tantangan dan penanganannya, Forum penelitian agro ekonomi, Volume 32 No. 2, Desember 2014: 123 - 135, Bogor.

Felippa Amanta \& Ira Aprilianti. 2020. Kebijakan Perdagangan Pangan Indonesia saat Covid-19, Jakarta , Center for Indonesian Policy Studies (CIPS).
Hanani, Nuhfil. "Strategi Pencapaian Ketahanan Pangan Keluarga". Jurnal Ekonomi Pertanian, 1(1), 2012.

Laporan akhir "Analisis dan Evaluasi Hukum dalam rangka peningkatan Kedaulatan Pangan", Pusat Analisis dan Evaluasi Hukum Nasional, Kementerian Hukum dan HAM Republik Indonesia, 2016.

Lukman Adam, Kinerja ekonomi pangan nasional: dinamika dan reformulasi kebijakan, 2014. Jurnal Ekonomi \& Kebijakan Publik, Vol. 5 No. 2, Desember 2014173 -192. Jakarta: P3DI Bidang Ekonomi \& Kebijakan Publik.

McKibbin, W. \& Fernando, R. (2020). The Global Macroeconomic Impacts of COVID-19: Seven Scenarios. Centre for Applied Macroeconomic Analysis, the Australian National University.

Pribadi, N. "Kebijakan Nasional Pemantapan Ketahanan Pangan ", makalah pada Lokakaya Ketahanan Pangan Nasional, Yayasan Lembaga Konsumen Indonesia (YLKI) dan Consumers International Regional Office for Asian and the Pasific (CIROAP), Jakarta, 28-29 Agustus 2001.

Syahyuti, Sunarsih, Sri wahyuni, Wahyuning k. Sejati, dan Miftahul azis, Kedaulatan pangan sebagai basis untuk mewujudkan ketahanan pangan nasional, Bogor: Forum Penelitian Agro Ekonomi, Vol. 33 No. 2, Desember 2015: 95-109, 2015.

Syahyuti. "Paradigma Kedaulatan Pangan dan Keterlibatan Swasta: Ancaman Terhadap Pendekatan Ketahanan Pangan (?)". Analisis Kebijakan Pertanian, 9(1), 2011.

Tadjuddin Noer Effendi, "Membangun Budaya dan Menguatkan Kearifan Pangan Lokal Berbasis Spirit Kultural Bangsa Indonesia", Makalah disampaikan pada Seminar Akselerasi Pemantapan Ketahanan Pangan Melalui Sinergi Pemberdayaan Potensi Eksisting dan Budaya Lokal Menuju Kemandirian dan Kedaulatan Pangan, 29 November 2012, Medan. 